\title{
Fatores de rico para doenças cardiovasculares em adolescentes de Caxias do Sul-RS, Brasil
}

\author{
Cardiovascular risk factors in adolescents from Caxias do Sul, \\ RS, Brazil
}

Daniel Giordani Vasques ${ }^{1}$

Resumo - Apesar de a maior parte das doenças cardiovasculares ocorrerem na fase adulta da vida, o processo inicia-se, muitas vezes, ainda na adolescência. Objetivou-se analisar fatores de risco cardiovascular em adolescentes de Caxias do Sul-RS. Neste estudo epidemiológico de corte transversal, analisou-se dados de 1675 adolescentes de 11 a 17 anos, selecionados de forma aleatória por conglomerados a partir do setor do município, tipo de escola e série de ensino. As prevalências de fatores de risco foram: histórico familiar (82,4\%), dieta aterogênica (74,7\%), baixa aptidão cardiorrespiratória (61,6\%), sedentarismo $(55,8 \%)$, pressão arterial elevada $(28,4 \%)$, adiposidade abdominal aumentada $(27,7 \%)$, excesso de gordura corporal $(26,5 \%)$, etilismo $(22,3 \%)$, excesso de peso corporal $(19,7 \%)$, tabagismo $(6,2 \%)$ e consumo abusivo de álcool $(4,3 \%)$. Os rapazes apresentaram maior prevalência de dieta aterogênica $(79,4 \%>70,7 \%)$, enquanto as moças de sedentarismo $(66,8 \%>43,2 \%)$, baixa aptidão cardiorrespiratória $(69,4 \%>53,0 \%)$, tabagismo $(7,9 \%>4,3 \%)$, adiposidade abdominal aumentada $(32,9 \%>21,7 \%)$ e excesso de gordura corporal $(32,5 \%>19,7 \%)$. Nas moças, associou-se ao sedentarismo a faixa etária de 15-17 anos $(\mathrm{RP}=1,30)$, residir em até quatro pessoas $(\mathrm{RP}=1,17)$, expor-se elevadamente a comportamentos sedentários $(\mathrm{RP}=1,21)$, apresentar dieta aterogênica $(\mathrm{RP}=1,12)$ e possuir baixa aptidão $(\mathrm{RP}=1,21)$. Nos rapazes, o sedentarismo associou-se à baixa aptidão $(\mathrm{RP}=1,21)$. A baixa aptidão cardiorrespiratória associou-se nas moças à faixa etária de 15-17 anos $(\mathrm{RP}=1,43)$ e a possuir mãe sedentária $(\mathrm{RP}=1,13)$, e nos rapazes ao deslocamento passivo à escola $(\mathrm{RP}=1,18)$. Para as moças e os rapazes, respectivamente, o sedentarismo $(\mathrm{RP}=1,19$ e $\mathrm{RP}=1,17)$, o excesso de peso $(\mathrm{RP}=1,16$ e $\mathrm{RP}=1,24)$ e o excesso de gordura corporal $(\mathrm{RP}=1,14$ e $\mathrm{RP}=1,51)$ associaram-se à baixa aptidão. Intervenções em atividade física devem focar principalmente as moças, com idades de 15 a 17 anos, que residam em até quatro pessoas e possuam exposição a comportamentos sedentários. Recomenda-se maior atenção às moças em intervenções em atividade física, tabagismo e excesso de peso, e aos rapazes, nos hábitos alimentares.

Palavras-chave: Fatores de risco; Adolescentes; Atividade física; Obesidade.

Abstract - Although most cardiovascular diseases occur in adult life, the process frequently starts during adolescence. The objective of this study was to analyze cardiovascular risk factors in adolescents from Caxias do Sul, RS. In this cross-sectional epidemiological study, data from 1675 adolescents aged 11 to 17 years and selected by random cluster sampling according to city sector, type of school and school grade were analyzed. The following prevalences of risk factors were observed: family history (82.4\%), atherogenic diet (74.7\%), low cardiorespiratory fitness $(61.6 \%)$, sedentariness $(55.8 \%)$, elevated blood pressure (28.4\%), increased waist circumference (27.7\%), excess body fat (26.5\%), alcoholism (22.3\%), excess body weight (19.7\%), smoking (6.2\%), and alcohol abuse (4.3\%). The prevalence of an atherogenic diet was higher among boys $(79.4 \%$ vs $70.7 \%)$, whereas girls presented a higher prevalence of sedentariness $(66.8 \%$ vs $43.2 \%)$, low cardiorespiratory fitness (69.4\% vs 53.0\%), smoking (7.9\% vs $4.3 \%)$, increased waist circumference (32.9\% vs $21.7 \%$ ), and excess body fat (32.5\% vs $19.7 \%)$. In girls, sedentariness was associated with age 15-17 years $(P R=1.30)$, living with up to four persons $(P R=1.17)$, a sedentary behavior of more than 14 hours/week $(P R=1.21)$, atherogenic diet $(P R=1.12)$, and low fitness $(P R=1.21)$. In boys, sedentariness was associated with low fitness $(P R=1.21)$. Low

1 Universidade Federal de Santa Catarina. Centro de Desportos. Mestrado em Educação Física. Florianópolis, SC. Brasil. 2008.

Orientador: Prof. Dr. Adair da Silva Lopes. cardiorespiratory fitness was associated with age $15-17$ years $(P R=1.43)$ and having a sedentary mother $(P R=1.13)$ in girls, and with passive transport to school $(P R=1.18)$ in boys. Sedentariness $(P R=1.19$ and 1.17), excess weight $(P R=1.16$ and 1.24) and excess body fat $(P R=1.14$ and 1.51$)$ were associated with low fitness in girls and boys, respectively. Physical activity interventions should mainly focus on girls aged 15 to 17 years who live with up to four persons at home and are exposed to sedentary behaviors. More attention to girls is recommended regarding physical activity interventions, smoking, and excess weight, and to boys, regarding dietary habits

Key words: Risk factors; Adolescents; Physical activity; Obesity. 